\title{
Interactions of proteins with biogenic iron oxyhydroxides and a new culturing technique to increase biomass yields of neutrophilic, iron-oxidizing bacteria
}

\section{Roman A. Barco and Katrina J. Edwards*}

Department of Biological Sciences, University of Southern California, Los Angeles, CA, USA

\section{Edited by:}

Mark Alexander Lever, Aarhus

University, Denmark

\section{Reviewed by:}

William D. Orsi, Woods Hole

Oceanographic Institution, USA

Elizabeth Maria Percak-Dennett,

University of Wisconsin Madison,

USA

\section{*Correspondence:}

Katrina J. Edwards, Department of Biological Sciences, University of Southern California, 3616 Trousdale Parkway, AHF 203, Los Angeles, CA 90089-4012, USA

e-mail:kje@usc.edu

\begin{abstract}
Neutrophilic, bacterial iron-oxidation remains one of the least understood energy-generating biological reactions to date. One of the reasons it remains under-studied is because there are inherent problems with working with iron-oxidizing bacteria ( $\mathrm{FeOB}$ ), including low biomass yields and interference from the iron oxides in the samples. In an effort to circumvent the problem of low biomass, a new large batch culturing technique was developed. Protein interactions with biogenic iron oxides were investigated confirming that such interactions are strong. Therefore, a protein extraction method is described to minimize binding of proteins to biogenic iron oxides. The combination of these two methods results in protein yields that are appropriate for activity assays in gels and for proteomic profiling.
\end{abstract}

\footnotetext{
Keywords: iron-oxidation, mariprofundus ferrooxydans, protein extractions, iron oxyhydroxides, chemolithoautotrophic bacteria
}

\section{INTRODUCTION}

Neutrophilic microbial iron oxidation is a biological reaction that has been known since the early 19th century (Kützing, 1833; Pringsheim, 1949). Yet it remains poorly understood when compared with other thoroughly investigated reactions such as sulfur oxidation, nitrogen fixation or iron reduction due to an array of difficulties including low biomass, lack of pure cultures, and interference of iron oxides with sample processing. The majority of the neutrophilic, iron-oxidizing bacteria $(\mathrm{FeOB})$ that have been isolated so far are obligate iron oxidizers; therefore, they cannot grow on media enriched in organic carbon as other groups of bacteria can (i.e., the iron reducing bacteria). These historical difficulties have contributed to the dearth of data on the basic physiology of neutrophilic $\mathrm{FeOB}$, despite important advances in the understanding of acidophilic and phototrophic FeOB.

There are several methods available to grow neutrophilic $\mathrm{FeOB}$, as recently reviewed by Emerson and Floyd (2005). These methods include the use of gradient tubes, gradient plates, solid media, and liquid media. From these methods, the most useful in isolating novel organisms from the environment has been the gradient tube method. This method consists of using small glass tubes that have a FeS plug at the bottom and a defined freshwater or marine medium stabilized with agarose overlaying the plug. Since the bottom FeS plug diffuses $\mathrm{Fe}(\mathrm{II})$ upwards and the $\mathrm{O}_{2}$ (g) diffuses downwards into the bottom of the tube, the two opposing gradients meet forming a microaerobic region where $\mathrm{FeOB}$ can grow and produce a sharp band of growth. The reddish band of growth containing oxidized iron and cells can then be carefully removed, serially diluted, and subcultured with the whole process repeated numerous times to obtain a pure $\mathrm{FeOB}$ culture. This method has been crucial in the isolation of many FeOB including Sideroxydans ES-1, Gallionella ES-2,
Mariprofundus ferrooxydans, and recently Ferriphaselus amnicola (Emerson and Moyer, 1997, 2002; Kato et al., 2013). But one of the problems is with this method is that it does not yield enough biomass for protein research, with total number of cells ranging $10^{6}-10^{7}$ per tube (Emerson and Moyer, 2002). A minimum of $10^{9}$ cells would be required to obtain approximately $100-150 \mu \mathrm{g}$ of protein (Bremer and Dennis, 1996), which is enough protein yield for proteomic analysis. However, if activity assays (i.e., ingel or based on spectroscopy) are planned, a minimum of $10^{10}$ cells should be planned. This would indicate that if the gradient tube method is employed, there would have to be thousands of tubes inoculated per experiment; this is clearly an impractical approach. Alternatively, the gradient plate method (i.e., with and without agarose) provides for more volume ( $15 \mathrm{mLs})$ and larger total cell numbers, but the number of plates needed per experiment would still be in the hundreds. Solid media is often not an option to grow autotrophic $\mathrm{FeOB}$, since they do not form classical bacterial colonies. The liquid medium method presented in Emerson and Floyd (2005) offers more volume than the gradient tube and gradient plate methods, but it is still relatively low in volume ( $40 \mathrm{mLs})$. An attractive factor in using the liquid medium is that it is more realistic to the true environment than the semisolid agarose medium, a factor that is important if we want to study the physiology of $\mathrm{FeOB}$ in a state that is comparable to their natural environments.

In addition to the above challenges, there is an inherent problem to studying $\mathrm{FeOB}$, which is the presence of iron oxyhydroxides (i.e., both biogenic and non-biogenic) in samples. This problem is known for the extraction of DNA in soil and rock samples, for example, where special commercial soil kits are recommended for consistent and appropriate yields of DNA for Polymerase Chain Reaction (PCR) experiments (Wang and 
Edwards, 2009). In the case of protein analysis, such amplification is not possible. However, there have been several studies that have shown that consistent protein extraction from sediment, soil, rock and wastewater can be attainable (Ogunseitan, 1993; Benndorf et al., 2007, 2009; Keiblinger et al., 2012). Nonetheless, protein extraction remains the biggest bottleneck in environmentalor laboratory based-proteomics due to the technical challenges ranging mainly from low yields, complexity of matrix, and humic acid interference (Bastida et al., 2009; Keller and Hettich, 2009; VerBerkmoes et al., 2009).

In this manuscript, a way to scale up culturing of the FeOB Mariprofundus ferrooxydans in liquid medium is presented for purposes of obtaining high-yields of biomass for subsequent proteomic experiments. We also present a method to separate cells from the stalks of biogenic iron oxides that can be useful for analysis of isolated cells. Both of these methods were shared and shortly described in Saini and Chan (2013) but we expand on the details and present new findings. Strong interactions of proteins with both synthesized and biogenic iron oxyhydroxide are also shown and proven to affect protein extractions. A method to circumvent this problem is presented.

\section{MATERIALS AND METHODS LARGE BATCH CULTURES}

To generate enough biomass needed for proteomic analysis, a new large-scale culturing method for $M$. ferrooxydans is described. M. ferrooxydans, strain PV-1 (hereinafter PV-1), is grown from a stock culture provided by David Emerson (Bigelow Laboratory for Ocean Sciences, East Boothbay, ME, USA). The liquid medium is adopted from Emerson and Floyd (2005) with modifications appropriate for scaling up to 100 and $800 \mathrm{~mL}$ cultures. The large batch cultures are grown in $1 \mathrm{~L}$ autoclavable polycarbonate bottles (VWR, Visalia, CA) each with $784 \mathrm{~mL}$ of medium. Immediately after autoclaving, the medium is sparged with $\mathrm{N}_{2}(\mathrm{~g})$ for $30 \mathrm{~min}$. The bottle is then sealed with an autoclaved rubber stopper \#6 coated in a thin film of silica gel and capped with an open-top cap. After the bottles cool to room temperature, $15.2 \mathrm{~mL}$ of sterile sodium bicarbonate solution and filter-sterilized $\mathrm{CO}_{2}$ (g) are added to adjust $\mathrm{pH}$ to $6.2-6.5$ (1.5 min at $15 \mathrm{psi}$; must check empirically). This is followed by addition of $800 \mu \mathrm{L}$ of vitamin cocktail (ATCC, Manassas, VA), $32 \mathrm{~mL}$ of filter-sterilized air and $3.2 \mathrm{~mL}$ of filter-sterilized $100 \mathrm{mM} \mathrm{FeCl}_{2}$ solution. The culture vessel is inoculated with $40 \mathrm{~mL}$ of log-phase PV-1 (approximately $10^{7}$ cells grown in $100 \mathrm{~mL}$ batch culture) and incubated in the dark, horizontally at room temperature without agitation. Iron is added every $24 \mathrm{~h}$. The headspace is gas-exchanged every $24 \mathrm{~h}$ with filter-sterilized $\mathrm{N}_{2}: \mathrm{CO}_{2}(70: 30 \mathrm{v} / \mathrm{v})(\mathrm{g})$ and $32 \mathrm{~mL}$ of filteredair. Active cultures in small bottles are maintained in log-phase by subculturing every $48 \mathrm{~h}$ until the start of the experiments. Cell counts to determine cell density for these experiments were performed as described in Emerson and Moyer (2002). Briefly, duplicate samples were fixed with paraformaldehyde solution ( $0.8 \%$ final concentration), stored at $4^{\circ} \mathrm{C}$ for $1 \mathrm{~h}$ and then frozen at $-20^{\circ} \mathrm{C}$ until counted. Slides printed with $4 \mathrm{~mm}$ diameter circles (Electron Microscopy Sciences, Fort Washington, PA) were coated with $1 \%$ agarose solution and allowed to cool. A sample volume of $4-2 \mu \mathrm{L}$ of resuspended culture sample mixed

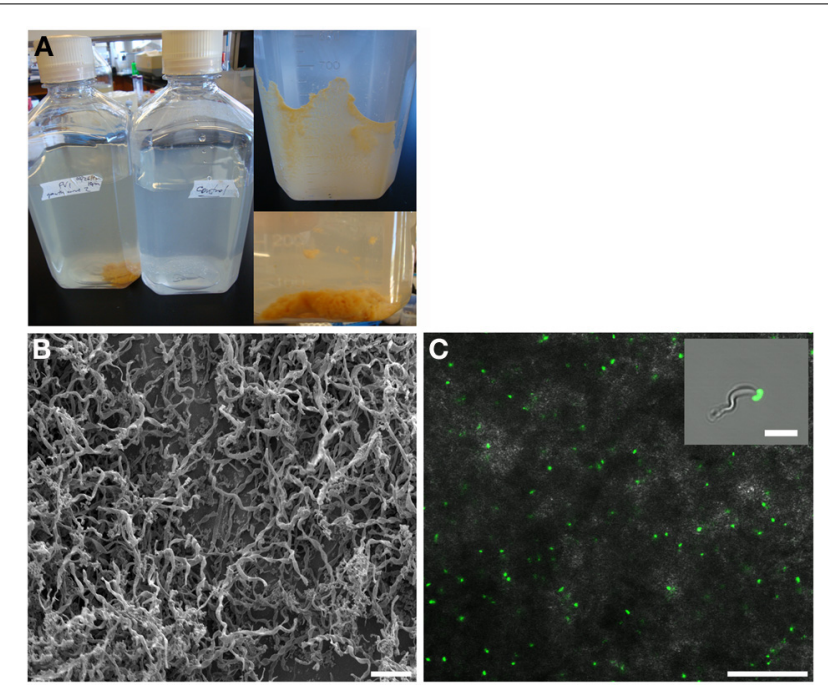

FIGURE 1 | (A) Left: large batch culture of $M$. ferrooxydans, strain PV-1 after 1 day of growth, compared to a control. Top-Right: formation of biofilm along the wall of culture bottle after 1 day of growth. Bottom-Right: the biofilm dislodges and forms fluffly flocculent material. (B) s.e.m. image of the mats of PV-1 (bar $=10 \mu \mathrm{m})$. (C) Confocal fluorescent and bright field composite image of the mats of PV-1 (bar $=25 \mu \mathrm{m})$. Inset: composite image of isolated PV-1 cell and stalk (bar $=4 \mu \mathrm{m})$.

with $2 \mu \mathrm{L}$ of $1 \mathrm{mM}$ propidium iodide solution (Life Technologies, Grand Island, NY) — was loaded within the boundaries of the circle and allowed to dry in the dark. Fifty fields per circle were counted at 100X magnification using an epifluorescent Axiostar Plus microscope equipped with an HBO 50 mercury lamp and Cy3 filter for green light excitation. Alternatively, samples were imaged on a TCS SPE confocal microscope (Leica Mycrosystems, Buffalo Grove, IL) using a $488 \mathrm{~nm}$ solid-state laser for excitation and emission wavelengths of 495-550 nm for SYTO 9 dye.

\section{PROTEIN INTERACTION WITH IRON OXIDES}

For each interaction experiment, the mats of log-phase PV-1 were directly harvested from 2 small batch cultures by pipetting and centrifuged at $10,000 \times g$ for $5 \mathrm{~min}$. The pelleted mats were washed with 50 volumes of milli-Q water to 1 volume of mats 3 times. Each washing step was followed by centrifugation at $10,000 \times g$ for $5 \mathrm{~min}$. The mats were then resuspended in either $50 \mathrm{~mL}$ of $20 \mathrm{mM}$ sodium acetate buffer, $\mathrm{pH} 5.25$ (for experiments with cytochrome $c$ ), or $20 \mathrm{mM}$ Tris Base buffer, $\mathrm{pH} 8.0$ (for experiments with bovine serum albumin, BSA) and loaded into sealed Econo-Pac ${ }^{\circledR}$ chromatography columns $(1.5 \times 12 \mathrm{~cm})$ (Bio-Rad, Hercules, CA) in a minimal volume of buffer. The final volume of packed mats of PV-1 was $0.8 \mathrm{~mL}$. The mats were then spiked with $50 \mu \mathrm{g}$ of either cytochrome $c$ from horse's heart $(1 \mathrm{~mL}$ of $50 \mu \mathrm{g} / \mathrm{mL}$ fresh stock in $20 \mathrm{mM}$ sodium acetate buffer, $\mathrm{pH} 5.25$ ) (Sigma-Aldrich, St. Louis, MO) or BSA ( $1 \mathrm{~mL}$ of $50 \mu \mathrm{g} / \mathrm{mL}$ fresh stock in $20 \mathrm{mM}$ Tris base buffer, $\mathrm{pH}$ 8.0) (Bio-Rad). The sample was allowed to incubate for $15 \mathrm{~min}$ at room temperature with resuspension every $5 \mathrm{~min}$. After this incubation period, $5 \mathrm{~mL}$ fractions are collected while sodium acetate buffer (for cytochrome 


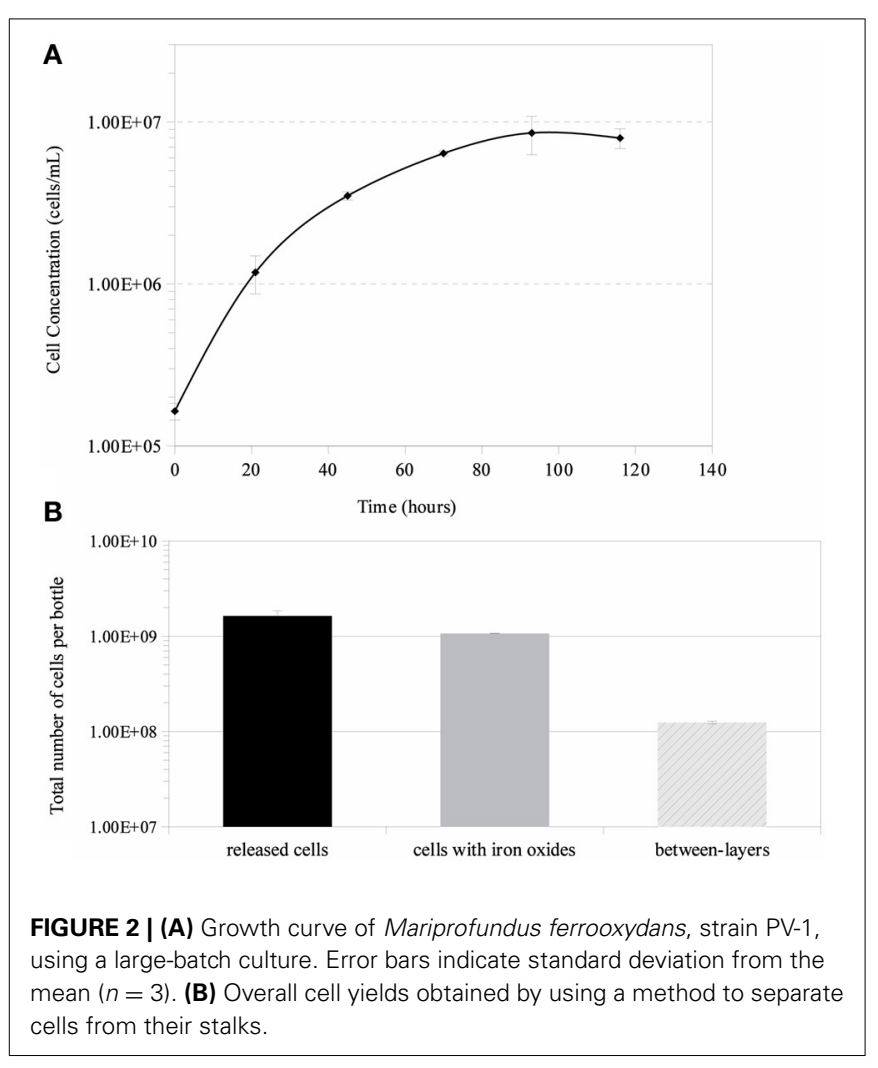

$c$ experiment) or Tris buffer (for BSA experiment) is continually added to the column. Starting with the 5th fraction, either $0.1 \mathrm{~N} \mathrm{NaOH}$ solution (for both cytochrome $c$ or BSA) or $1 \mathrm{M}$ $\mathrm{NaCl} / 20 \mathrm{mM}$ sodium acetate buffer, $\mathrm{pH} 5.25$ (for cytochrome $c$ experiment) or $1 \mathrm{M} \mathrm{NaCl} / 20 \mathrm{mM}$ Tris base buffer, $\mathrm{pH} 8.0$ (for BSA experiment) was added to the column. A total of 14 fractions were collected per experiment, which are performed in duplicates. Protein concentrations were measured by the Bradford Assay (Bio-Rad).

\section{PREPARATION OF 2-LINE FERRIHYDRITE}

The method of Schwertmann and Cornell (2000) was used to produce 2-line ferrihydrite (2LF). Forty g of $\mathrm{Fe}\left(\mathrm{NO}_{3}\right)_{3} \cdot 9 \mathrm{H}_{2} \mathrm{O}$ was dissolved in $500 \mathrm{~mL}$ of milli-Q water. To this solution, $330 \mathrm{~mL}$ of $1 \mathrm{M} \mathrm{KOH}$ was slowly added to bring the $\mathrm{pH}$ to a value between 7 and 8 . The mixture was then aliquoted into $50 \mathrm{~mL}$ tubes and washed three times in milli-Q water by centrifuging at $10,000 \times g$ for $10 \mathrm{~min}$ at $4^{\circ} \mathrm{C}$. The pellets were frozen at $-20^{\circ} \mathrm{C}$ for 1 day and oven dried for another day at $50^{\circ} \mathrm{C}$. This freezing/drying procedure was repeated 3 times. The dried product was ground to particle size $>180 \mu \mathrm{m}$ and $<355 \mu \mathrm{m}$. Before the start of the experiments, 1 gram of synthetic $2 \mathrm{LF}$ was washed 5 additional times with $50 \mathrm{~mL}$ of milli-Q water. The synthetic $2 \mathrm{LF}$ was then resuspended in $50 \mathrm{~mL}$ of buffer $(20 \mathrm{mM}$ sodium acetate, $\mathrm{pH} 5.25$ for cytochrome $c$ experiments or $20 \mathrm{mM}$ Tris Base, $\mathrm{pH} 8.0$ for BSA experiments) and loaded into a sealed Econo-Pac ${ }^{\circledR}$ chromatography column in a minimal volume of buffer to cover it. The synthetic $2 \mathrm{LF}$ had a volume of $0.8 \mathrm{~cm}^{3}$ in the column. Samples were spiked as indicated in the last section and were incubated

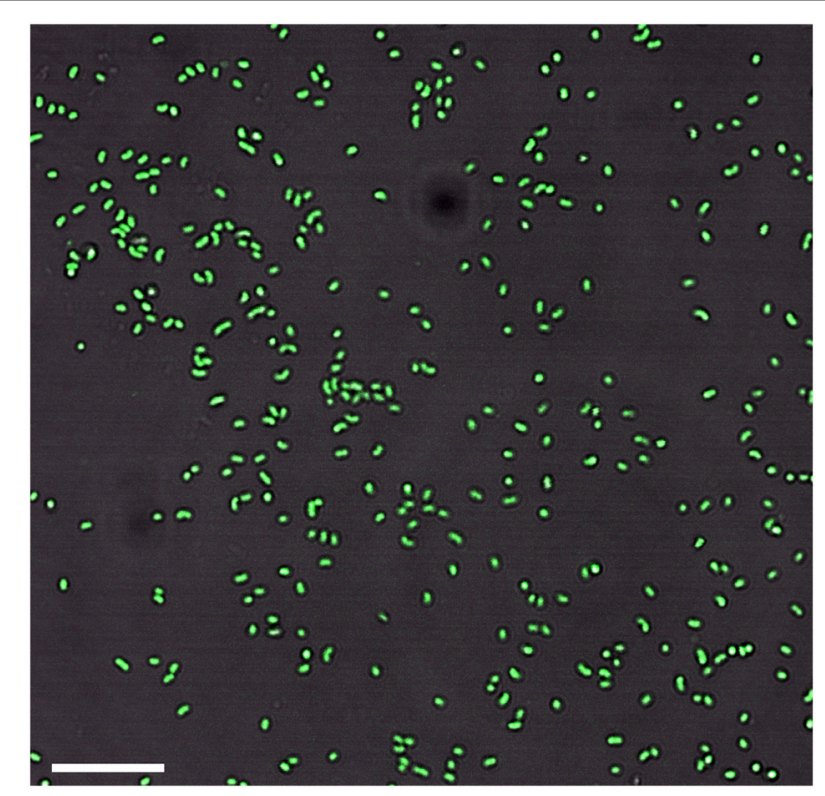

FIGURE 3 | Enrichment of cells without stalks after the sample goes through the cell-separation method (bar $=10 \mu \mathrm{m}$ ).

for $15 \mathrm{~min}$ at room temperature with resuspension of materials every $5 \mathrm{~min}$. The mineral was characterized at the Los Angeles National History Museum by X-ray diffraction (XRD) to confirm its identity. Data were recorded using a R-Axis Rapid II (Rigaku, The Woodlands, TX) curved imaging plate microdiffractometer with monochromatized MoK $\alpha$ radiation. Observed $d$ spacings and intensities were derived by profile fitting using JADE 2010 software (Materials Data Inc., Livermore, CA).

\section{PROTEIN EXTRACTION}

\section{Osmotic-shock fraction}

A total of $8 \mathrm{~L}$ of late-log phase PV-1 culture was harvested by filtration on $0.22 \mu \mathrm{m}$ mesh black Whatman-Nucleopore polycarbonate filters (GE Healthcare Life Sciences, Piscataway, NJ) with $10 \mu \mathrm{m}$ support TCTP filter (EMD Millipore, Billerica, MA). PV-1 mats were treated for osmotic-shock by immersing the filters in $30 \mathrm{~mL}$ of $40 \mathrm{mM}$ Tris-Base $\mathrm{pH}$ 8.5/20\% sucrose solution followed by addition of $60 \mu \mathrm{L}$ of $0.5 \mathrm{M}$ EDTA, $\mathrm{pH} 8.0$ and stirring slowly at room temperature for $10 \mathrm{~min}$ ( $\mathrm{Neu}$ and Heppel, 1965). The mixture was centrifuged at $14,000 \times g$ for $10 \mathrm{~min}$ at $4^{\circ} \mathrm{C}$ and the supernatant discarded. The pellet was resuspended in $30 \mathrm{~mL}$ of ice cold, sterile $5 \mathrm{mM} \mathrm{MgCl}_{2}$ and incubated on ice for $10 \mathrm{~min}$ with slow stirring for osmotic shock (Ausubel et al., 1989). The mixture was centrifuged again at $14,000 \times g$ for $10 \mathrm{~min}$. The supernatant was saved and stored at $-20^{\circ} \mathrm{C}$. The osmotic-shock fraction was quantitated by using the Quick Start ${ }^{\mathrm{TM}}$ Bradford Assay (Bio-Rad), according to manufacturer's instructions using an UV-1601 spectrophotometer (Shimadzu Scientific Instruments, Carlsbad, CA).

\section{Crude extract}

A total of $8 \mathrm{~L}$ of late-log phase PV-1 culture was harvested as described above. The filters were incubated in $40 \mathrm{~mL}$ of $0.1 \mathrm{~N}$ 


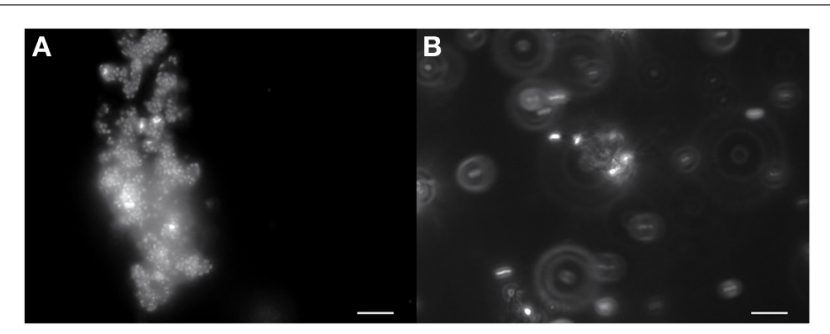

FIGURE 4 | (A) PV-1 cells in the mat tend to clump together as the iron in the stalks dissolves with $0.2 \mathrm{M}$ oxalic acid at $\mathrm{pH} 1$. The cells stain red when live/dead stained (dead cells) and stick to a white material that remains undissolved. (B) PV-1 cells treated with $0.2 \mathrm{M}$ oxalic acid at a higher $\mathrm{pH}$ of 3. The majority of cells are no longer static (hard to focus image) and stain green when live/dead stained (live cells). Some of the white material still remains in the sample and a minority of cells stick to its surface. Bar = $10 \mu \mathrm{m}$.

$\mathrm{NaOH}$ solution on ice for $15 \mathrm{~min}$ with vigorous vortexing for $30 \mathrm{~s}$ every $3 \mathrm{~min}$ to lyse cells and release proteins. The mixture was centrifuged at $14,000 \times g$ for $10 \mathrm{~min}$ at $4^{\circ} \mathrm{C}$ to pellet cellular debris and iron oxides. The clarified supernatant was saved and stored at $-20^{\circ} \mathrm{C}$. The resulting pellet was immersed in another $40 \mathrm{~mL}$ of $0.1 \mathrm{~N} \mathrm{NaOH}$ solution and processed as described above to maximize protein yields. The combined, clarified supernatants were concentrated and buffer-exchanged with $40 \mathrm{mM}$ Tris-Base, $\mathrm{pH} 8.5$ by using Macrosep 3K concentrators (Pall, Ann Arbor, MI) with a $3 \mathrm{kDa}$ molecular weight cutoff (MWCO) membrane according to manufacturer's instructions. The above procedure resulted in a concentrated orange crude extract containing both insoluble and soluble proteins, which was then frozen at $-20^{\circ} \mathrm{C}$ until further analysis.

\section{CELL SEPARATION}

A total of $2.4 \mathrm{~L}$ ( $0.8 \mathrm{~L}$ triplicates $)$ of log phase cultures were harvested as described above. The filters were immersed in total volume of $250 \mathrm{~mL}$ of cold, filter-sterilized $0.2 \mathrm{M}$ oxalic acid, $\mathrm{pH}$ 3.0 for two hours with mixing on a shaker table. The oxalic acid partially dissolves the stalks of iron oxides so that the cells are released. The mixture was centrifuged at $14,000 \times g$ for $10 \mathrm{~min}$ at $4^{\circ} \mathrm{C}$ to pellet the resulting white paste material and the cells. The supernatant was discarded and the pellet is resuspended in $8 \mathrm{~mL}$ of sterile artificial seawater medium (ASW). The resuspended material $(4 \mathrm{~mL} \times 2$ tubes) was mixed with filter-sterilized $0.001 \%$ resazurin $(0.2 \mathrm{~mL})$ and carefully layered over a filter-sterilized Nycodez $^{\circledR}$ solution with $1.3 \mathrm{~g} / \mathrm{mL}$ density $(12 \mathrm{~mL}$ ) (Axis-Shield, Oslo, Norway) in a sterile, polypropylene $50 \mathrm{~mL}$ conical tube. Resazurin does not readily mix with Nycodenz and helps visualize the top layer containing the cells. The tube was centrifuged at $10,000 \mathrm{rpm}$ for $50 \mathrm{~min}$ at $4^{\circ} \mathrm{C}$ to separate cells from the white paste/stalks. Being careful not to disturb the two layers, the top pink layer and some of the Nycodenz were transferred into a new tube. The pink solution was diluted 1:2 with ASW to dilute any remaining Nycodenz and centrifuged at $14,000 \times g$ for $10 \mathrm{~min}$ at $4^{\circ} \mathrm{C}$. The resulting pellet, containing cells, was resuspended in a minimal amount of ASW or buffer of choice and processed for cell counting and/or protein extraction.

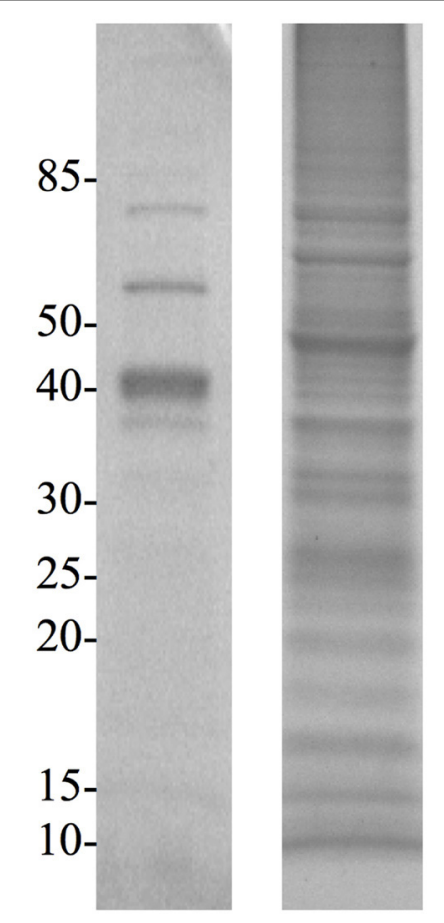

FIGURE 5 | SDS-PAGE gels of osmotic-shock fraction (left) and crude extract (right) stained with Coomassie Blue. Molecular masses (in kDa) are indicated on the left.

\section{SODIUM DODECYL SULFATE - POLYACRYLAMIDE GEL ELECTROPHORESIS (SDS-PAGE)}

Proteins were separated on gels at $90 \mathrm{~V}$ according to standard protocols (Laemmli, 1970). Soluble $(n=2)$ and solubilized membrane fractions $(n=2)$ were run on $12 \% \mathrm{TGX}^{\mathrm{TM}}$ polyacrylamide gels (Bio-Rad) under reduced and non-reduced conditions (i.e., no dithiothreitol (DTT) and no heating). Gels were stained with Bio-Safe Coomassie Stain (Bio-Rad) for $1 \mathrm{~h}$, destained with HPLC-grade water for $2 \mathrm{~h}$ and visualized with a Gel Doc ${ }^{\mathrm{TM}} \mathrm{XR}+$ imaging system (Bio-Rad) equipped with a white light transilluminator. Images were analyzed with Image Lab $^{\mathrm{TM}}$ software (Bio-Rad). Slices were excised as close as possible to the band of interest with a clean sterile scalpel, stored in HPLC-grade water at $4^{\circ} \mathrm{C}$ and immediately submitted for proteomic analysis.

\section{PROTEOMIC ANALYSIS}

Excised protein samples were submitted to the Children's Hospital of Los Angeles - Proteomic Core Facility for trypsin-digestion and LC-MS/MS on a Thermo LTQ-Orbitrap XL mass spectrometer (San Jose, CA) equipped with an Eksigent (Dublin, CA) Nanoliquid Chromatography 1-D plus system. The resulting MS/MS spectra were searched against the generated proteome of PV-1 in the Uniprot database (accession numbers: NZ_AATS01000001-AATS01000032; Singer et al., 2011) using the Proteome Discoverer SEQUEST Daemon search engine. Protein probabilities were assigned by the Protein Prophet algorithm (Nesvizhskii et al., 2003). The criteria for having a protein identified at $>95 \%$ probability is that there needs to 


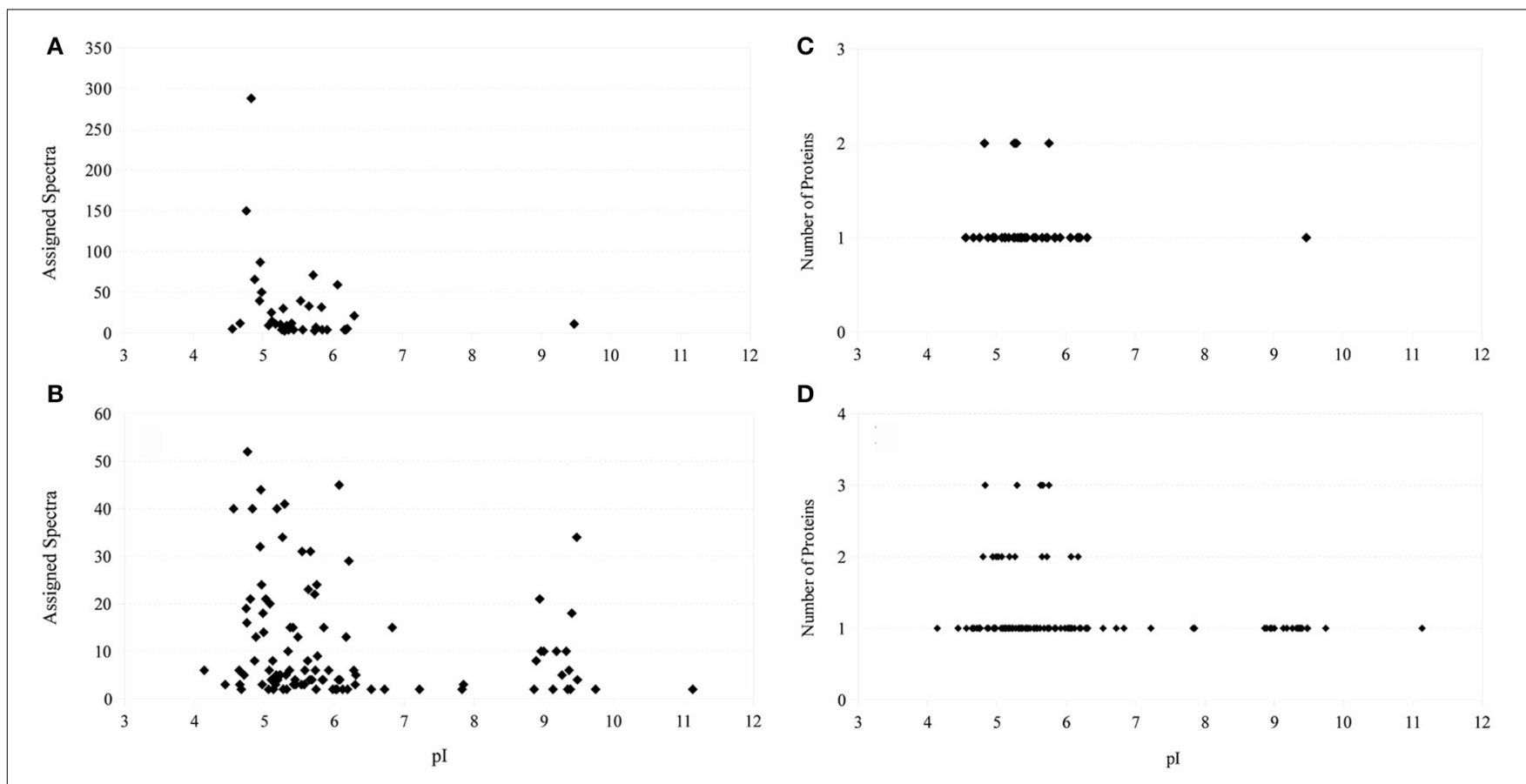

FIGURE 6 | Left: Number of assigned spectra as a function of isoelectric point of the identified protein (A: osmotic-shock sample; B: crude extract). Right: Number of proteins identified as a function of their isoelectric point (C: osmotic-shock sample; $\mathbf{D}$ : crude extract).
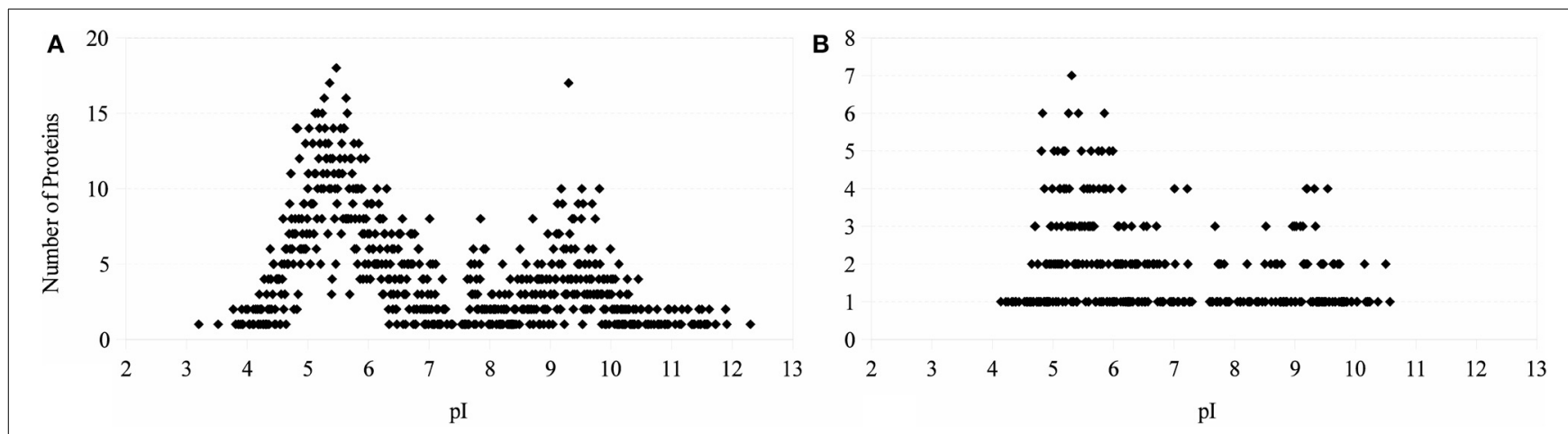

FIGURE 7 | Number of proteins as a function of isoelectric point. (A) Theoretical distribution based on the proteome of PV-1. (B) Theoretical distribution based on proteins with molecular weights between 33.6 and $51.1 \mathrm{kDa}$ (common range of $\mathrm{MW}$ of the proteins identified between osmotic-shock and crude fractions).

be a minimum of two unique peptides matching to it. Each peptide was established at $>95 \%$ probability $(<5 \%$ probability that it is a false positive match to the spectra) by the Scaffold Local FDR algorithm. Datasets were normalized based on the number of assigned spectra (i.e., number of peptides identified). Theoretical isoelectric points and molecular weights were generated by the ExPASy computational tool Compute pI/Mw by using Uniprot Knowledgebase accession numbers corresponding to the reference proteome of PV-1 (Gasteiger et al., 2005). Isoelectric point bias (b) were calculated as defined by Kiraga et al. (2007); $b=100\left(N_{\text {basic }}-N_{\text {acidic }}\right) /\left(N_{\text {basic }}+N_{\text {acidic }}\right)$, where $N_{\text {acidic }}$ and $N_{\text {basic }}$ represent the numbers of acidic and basic proteins, respectively. Statistical analysis was performed by using $\mathrm{JMP}^{\circledR}$, Version 11 (SAS Institute Inc., Cary, NC).
The mass spectrometry proteomics data have been deposited to the ProteomeXchange Consortium (Vizcaino et al., 2014) via the PRIDE partner repository with the dataset identifier PXD000937.

\section{SEM}

The sample was fixed in paraformaldehyde solution $(0.8 \%$ final concentration), incubated at $4^{\circ} \mathrm{C}$ for $1 \mathrm{~h}$ and stored at $-20^{\circ} \mathrm{C}$ afterwards. It was dehydrated sequentially in $25,50,75,90$, and $100 \%$ molecular grade ethanol with 10 min per dehydration step. Then it was critically-point-dried and gold coated. Images were taken with the scanning electron microscope JSM-7001F-LV (JEOL, Peabody, MA) at the Center for Electron Microscopy and Microanalysis at USC. 


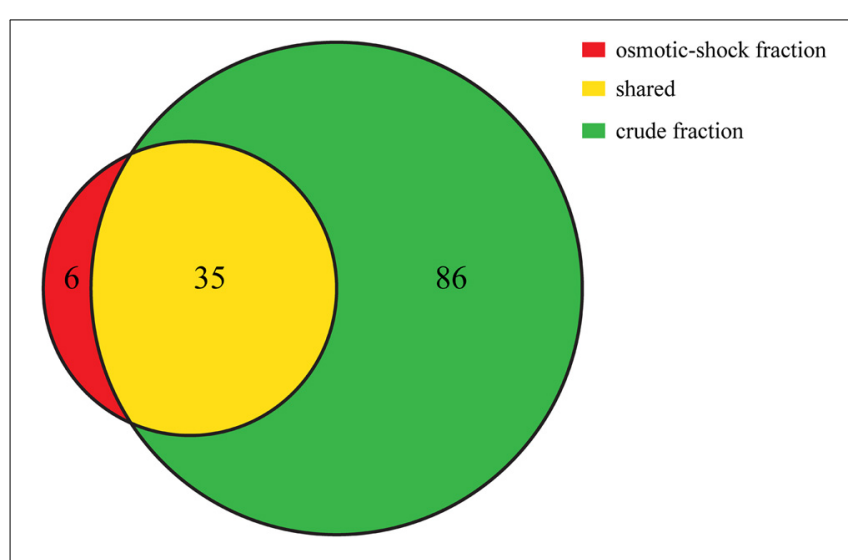

FIGURE 8 | Venn diagram showing the number of proteins that were uniquely identified in the osmotic-shock fraction (in red) and crude fraction (extracted with $\mathbf{N a O H}$; in green). Shared proteins between fractions are shown in yellow. Venn diagram is based on proteins identified with at least 2 peptides. All proteins identified in each fraction are listed in Supplemental Table 1.

\section{RESULTS}

Growth in a large-batch culture was successfully achieved with massive production of biofilm during the first $24 \mathrm{~h}$ of culture (Figure 1A). As the biofilm is disrupted, it forms flocculent material that tends to clump together and sink. The biofilm consists of cells and networks of stalks, with mostly biological products of iron oxidation seen as opposed to amorphous products of chemical iron oxidation (Figures 1B,C). Figure 2A shows a representative growth curve of PV-1 growing in a large batch culture. The doubling time is $10 \mathrm{~h}$. The stationary phase is reached at the third day of growth. With an initial concentration of $1.6 \times 10^{5}$ cells $/ \mathrm{mL}$, the cell density plateaus at an approximate average of $8.0 \times 10^{6}$ cells $/ \mathrm{mL}$. A total yield of $6.4 \times 10^{9}$ cells per single large batch culture is achieved. Figure 2B shows the number of cells that were released from the iron-oxide/stalks matrix following incubation on oxalic acid and centrifugation on a density gradient medium. The number of released cells was approximately $58 \%$ of the total number of cells in the large batch bottle (total yield of $2.8 \times 10^{9}$ cells). This fraction was more abundant than the fraction of cells that were still stuck in the iron-oxide/stalks matrix, which corresponded to $38 \%$ of the total population. There was a small fraction of cells $(<5 \%$ of total) that were present in-between the top and bottom layers. Figure 3 shows the enrichment of released cells and the absence of stalks. Incubation with oxalic acid at a $\mathrm{pH}<2$, dissolves the networks of stalks but makes the cells clump together in a white paste material (Figures 4A,B). Incubation with oxalic acid at $\mathrm{pH} 3$, only partially dissolves the network of stalks so that the cells are released without clumping.

Extraction of proteins following physical disruption of the PV-1 mats (i.e., bead-beating or sonication) yielded either zero bands or only a few faint bands on a coomassie-stained polyacrylamide gel after SDS-PAGE, even when cocktails of various detergents were used (results not shown). Yields were $<1 \mu \mathrm{g}$ of protein per L of culture. Similar results were obtained when PV1 mats were partially dissolved in oxalic acid and the cells were sonicated in the presence of a white material that does not dissolve. Alternatively, a treatment for osmotic-shock that did not disrupt the iron oxides, resulted in more protein extracted (ca. $3 \mu \mathrm{g}$ of protein per L of culture) compared to the other disruptive methods including bead-beating, sonication, and acidification. After this sample is run via SDS-PAGE, one of the strongest bands that stains with the coomassie stain was a band around $40 \mathrm{kDa}$ (Figure 5). When a duplicate gel was stained with the heme-stain it showed a weak positive result in an area that matches the molecular mass of $40 \mathrm{kDa}$. Following these results, a third gel was run via SDS-PAGE and the $40 \mathrm{kDa}$ band was excised and submitted for proteomic analysis. An analysis of the identified proteins indicated that most of them were cytoplasmic; thus, PV-1 cells were lysed by the osmotic-shock treatment (Supplemental Table S1). Remarkably, most of the proteins were acidic or negativelycharged (97.5\% of total proteins). Only 1 of 41 identified proteins were basic. In order to determine that the absence of basic proteins was due to a $\mathrm{pH}$ effect, the $\mathrm{pH}$ of the extraction solution was increased to $\mathrm{pH} 13$ by using $0.1 \mathrm{~N} \mathrm{NaOH}$ and without physically disrupting the mats. This approach yielded $>50 \mu \mathrm{g}$ of protein per $\mathrm{L}$ of culture. The sample was run via SDS-PAGE and the $40 \mathrm{kDa}$ band was excised and submitted for proteomic analysis (Figure 5). The results indicate that the protein extraction with $\mathrm{NaOH}$ circumvented the bias toward acidic proteins seen in the osmotic-shock treatment (Supplemental Table S1). From 121 proteins identified, 20 were basic (16.5\% of total proteins) and with theoretical subcellular localizations including the outer membrane, periplasm, and cytoplasm. Figure 6 shows that more basic and acidic proteins were identified following extraction in $0.1 \mathrm{~N} \mathrm{NaOH}$ (weighted average $\mathrm{pI}=5.83$; weighted $\sigma=1.42$ ), while mainly acidic proteins were identified following the osmotic-shock treatment (weighted average $\mathrm{pI}=5.19$; weighted $\sigma=0.61)$. A non-parametric Kolmogorov Smirnov two-sample test found that the distributions are significantly different $(p<0.0001)$.

The theoretical distribution of the $\mathrm{pI}$ values of the proteins generated from the proteome of PV-1 follows a bimodal pattern (Figure 7) that is seen in all organisms so far investigated, including prokaryotes (Schwartz et al., 2001; Knight et al., 2004; Kiraga et al., 2007). A bimodal distribution is also seen if the focus is on a subset of proteins with molecular weights similar to the proteins identified in the bands excised for proteomic analyses. The pI bias of the proteome of PV-1 is acidic $(b=-36.0)$, even when only the subset of proteins is taken into account $(b=-45.0)$. The pI bias calculated from the proteins extracted with $0.1 \mathrm{~N} \mathrm{NaOH}$ remains acidic $(b=-68.6)$ while the pI bias calculated from the proteins extracted via osmotic shock are extremely acidic $(b=-95.1)$ indicating that basic proteins are mostly absent in this latter fraction. Figure 8 shows that the protein extraction with $0.1 \mathrm{~N} \mathrm{NaOH}$ resulted in more proteins identified, including $85 \%$ of the proteins from the osmotic shock fraction.

Protein interaction experiments were designed to corroborate the results obtained by the proteomic analysis and to test if proteins were actually binding to the PV-1 mats. Figure 9A shows that cytochrome $c$, which is positively-charged at $\mathrm{pH} 5.25$, binds to the PV-1 mats. It remains in the mats even when elution with 


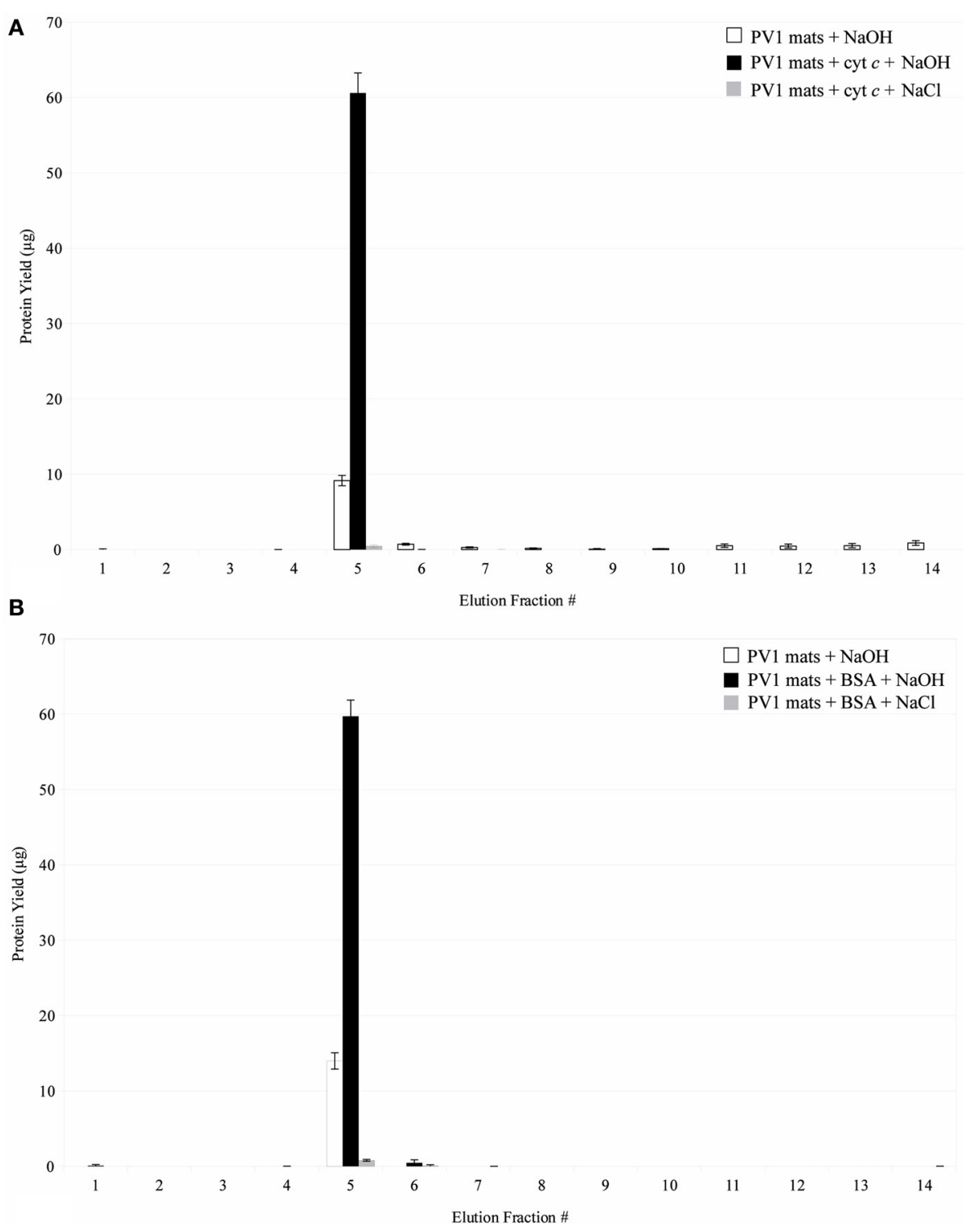

FIGURE 9 | (A) Interaction of cytochrome $c$ with biogenic iron oxyhydroxide. Fractions 1-4 were eluted in $20 \mathrm{mM}$ sodium acetate buffer, $\mathrm{pH}$ 5.25. Fractions 5-14 were eluted in $0.1 \mathrm{~N} \mathrm{NaOH}$ or $1 \mathrm{M}$ $\mathrm{NaCl}$. Error bars indicate \pm one standard deviation from the mean.
(B) Interaction of BSA with biogenic iron oxyhydroxide. Fractions 1-4 were eluted in $20 \mathrm{mM}$ Tris buffer, $\mathrm{pH}$ 8.00. Fractions 5-14 were eluted in $0.1 \mathrm{~N} \mathrm{NaOH}$ or $1 \mathrm{M} \mathrm{NaCl}$. Error bars indicate \pm one standard deviation from the mean.
$1 \mathrm{M} \mathrm{NaCl}$ is attempted, suggesting that a force stronger than electrostatic interaction is taking place between the protein and the mats. A pH increase of the elution solution to $\mathrm{pH} 13$ with $0.1 \mathrm{~N}$ $\mathrm{NaOH}$, eluted effectively the spiked content of cytochrome $c$. At this $\mathrm{pH}$, cytochrome $c$ is above its isoelectric point $(\mathrm{pI}=10.5)$; therefore, it would be negatively charged. The point zero charge (PZC) of the stalks of PV-1, the $\mathrm{pH}$ at which point the charge is neutral, is not known; however, it is a fair assumption that it will be negatively charged at $\mathrm{pH} 13$. This is because the PZC of pure poorly crystalline $2 \mathrm{LF}$ has a value that is 8.11-8.3 (Appelo et al., 2002; Lafferty and Loeppert, 2005), which would indicate that above this $\mathrm{pH}$ the surface charge of the mineral is negative.
While the composition of the stalk is not known in detail, 2LF is directly associated with it (Edwards et al., 2003; Toner et al., 2009; Chan et al., 2011) (Figure 10). Therefore, at pH 13, negative charge repulsion can explain that cytochrome $c$ was eluted at this high $\mathrm{pH}$.

Figure 9B shows that BSA, which is negatively-charged at $\mathrm{pH}$ 8.00 , also binds to the PV-1 mats. Similarly to cytochrome $c$, it is retained in the mats even when elution with $1 \mathrm{M} \mathrm{NaCl}$ is attempted. As mentioned above, this suggests that more direct interactions than electrostatic forces are taking place between the protein and the mats. This can include hydrophobic interactions. A pH increase to $\mathrm{pH} 13$, eluted effectively the spiked content of 


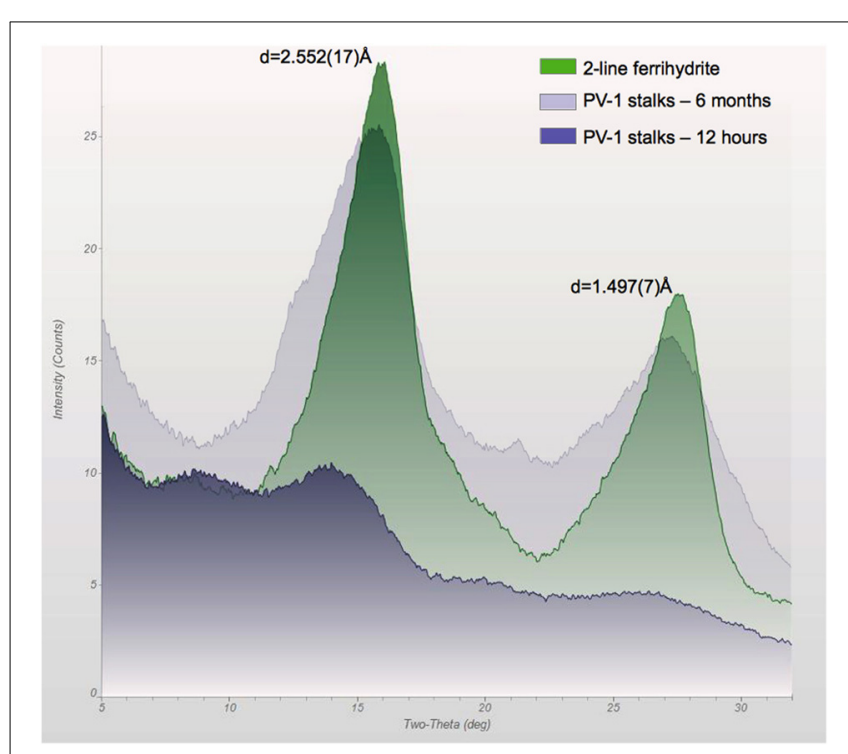

FIGURE 10 | X-ray diffraction pattern of the stalks of PV-1 compared to synthetic 2LF, showing the development of slightly more crystallized iron oxyhydroxide with time. At $12 \mathrm{~h}$, the sample was growing at log-phase and the biofilm had an off-white/light yellow color. At 6 months, the sample was reddish. At 3 days of growth, the sample had an orange/reddish color which generated a similar spectrum as the $12 \mathrm{~h}$ sample (data not shown). The $d$-spacing values correspond to $2 \mathrm{LF}$ for this synthetic material.

BSA, which is still negatively-charged because it is above its pI value of 4.75. At $\mathrm{pH} 8.00$; it is unclear what charge the stalks would have because its PZC is not known. At $\mathrm{pH} \mathrm{13}$, because it is such an extreme $\mathrm{pH}$, it is assumed that the stalks would be negatively-charged. Thus, negative charge repulsion can likely explain our observations that BSA was eluted at $\mathrm{pH} 13$.

In comparison to the control using synthetic 2LF (Figure 10), PV-1 mats have a lower retention capacity of the proteins spiked. This indicates that it is easier to desorb proteins from PV-1 mats than from synthetic 2LF. At $\mathrm{pH} 5.25$, positively-charged cytochrome $c$ binds to positively-charged $2 \mathrm{LF}(\mathrm{PZC}=8.11-8.33)$. In this case, repulsion is expected but the 15 min contact time, allows for the proteins to bind effectively to synthetic $2 \mathrm{LF}$. The desorption of cytochrome $c$ from synthetic 2LF was complete but took five fractions of $0.1 \mathrm{~N} \mathrm{NaOH}$ to achieve it (fractions 5-9). In comparison, cytochrome $c$ was desorbed from PV-1 mats effectively with the first fraction of $0.1 \mathrm{~N} \mathrm{NaOH}$ added (Figure 11A).

Figure 11B shows that at $\mathrm{pH} 8.00$, negatively-charged BSA binds to positively-charged synthetic 2LF. The desorption of BSA from synthetic 2LF is only partially achieved, with synthetic 2LF retaining close to half of the original amount of BSA spiked after elution is attempted with $0.1 \mathrm{~N} \mathrm{NaOH}$. In this latter case, the higher protein retention capacity observed in synthetic $2 \mathrm{LF}$ can be explained by a combination of electrostatic forces as well as direct mineral-protein interaction (i.e., hydrophobic interaction), which is a type of interaction that can be irreversible (Dobrikova et al., 2007; Rocker et al., 2009; Safi et al., 2011). Spiked BSA was only minimally eluted with $1 \mathrm{M} \mathrm{NaCl}$, which would indicate that the hydrophobic interactions between the protein and mineral play a major role than the electrostatic forces involved.

\section{DISCUSSION}

One of the goals of this study was to develop practical methods to increase biomass of $\mathrm{FeOB}$ so that proteomic studies could be realized. Past studies have shown that $10^{9}$ cells of Escherichia coli and Streptomyces coelicolor yield 100-150 $\mu \mathrm{g}$ and $143-181 \mu \mathrm{g}$ of protein respectively (Bremer and Dennis, 1996; Cox, 2004). Using these numbers as guidelines, and the minimum requirements of $30-50 \mu \mathrm{g}$ of protein for a full proteomic profile via LC-MS/MS, the goal is to achieve a minimum of $10^{9} \mathrm{M}$. ferrooxydans cells per experiment. This total cell number yields enough protein to use for proteomic analysis, with enough material for a possible technical replicate. However, if spectroscopic analysis or activity in-gel assays are planned (e.g., staining with heme-stain), then a minimum cell number of $10^{10}$ needs to be targeted so that protein yields are closer to $1 \mathrm{mg}$. The growth curve obtained from the large batch cultures (Figure 1) show a cell density of $>10^{6}$ cells $/ \mathrm{mL}$ and that a total number of cells of $10^{9}$ can be achieved per bottle within $24 \mathrm{~h}$. This can be compared to total cell numbers of $10^{7}$ within $24 \mathrm{~h}$ using other types of cultivation methods such as the gradient plate method (Emerson et al., 2007). The growth curve also shows that the cell densities have intermediate values compared with other previously published cell densities of $10^{6}$ to $10^{7}$ cells/mL (Emerson et al., 2007; Chan et al., 2011). Cultivation with 10 large bottles (i.e., total of $8 \mathrm{~L}$ of culture), following the method presented herein, produces enough biomass $\left(10^{10}\right.$ cells $)$ for proteomic analysis and in-gel activity assays. Alternatively, a more concentrated inoculum should also increase final cell yields.

The doubling time of $10 \mathrm{~h}$ reported in this study was calculated for the first $45 \mathrm{~h}$ of growth. If it is calculated during the first day of growth, as seen in a recent paper by Kikuchi et al. (2014), the doubling time is $7 \mathrm{~h}$ which is the same value obtained with Kikuchi's diffusion chamber method. The longer than usual doubling times of PV-1 that were determined by Kikuchi et al. (2014) when testing the liquid batch culture method may have to do with the addition of a single -high- dose of $\mathrm{Fe}^{2+}$ at $t=0 \mathrm{~h}$, a practice that is not consistent with the protocols in Emerson and Floyd (2005) for liquid batch cultures which call for daily addition of lower concentrations of Fe. Addition of excessive amounts of Fe at $t=0 \mathrm{~h}$ sequesters more than usual levels of phosphate in the medium, which in turn increases the doubling time of PV-1. The identification of two proteins that are associated with ABC-phophate-transporters (NCBI GI numbers: 114777113 and 114777114) identified in this study, support the explanation that PV-1 goes through phosphate limitation by the time of harvest (third day of growth). Therefore, even higher levels of Fe in the medium should exacerbate this effect.

The other goal of this study was to present methods to facilitate protein extraction for proteomic analysis of cells that are in close contact with biogenic iron oxides. Experiments on the interactions of proteins with the mats of PV-1 originated with extractions using disruptive forces such as bead-beating, sonication, and even acidification of sample; all of these methods consistently resulted in low yields of proteins in the presence or absence of detergents. Another hint was given when the non-disruptive 


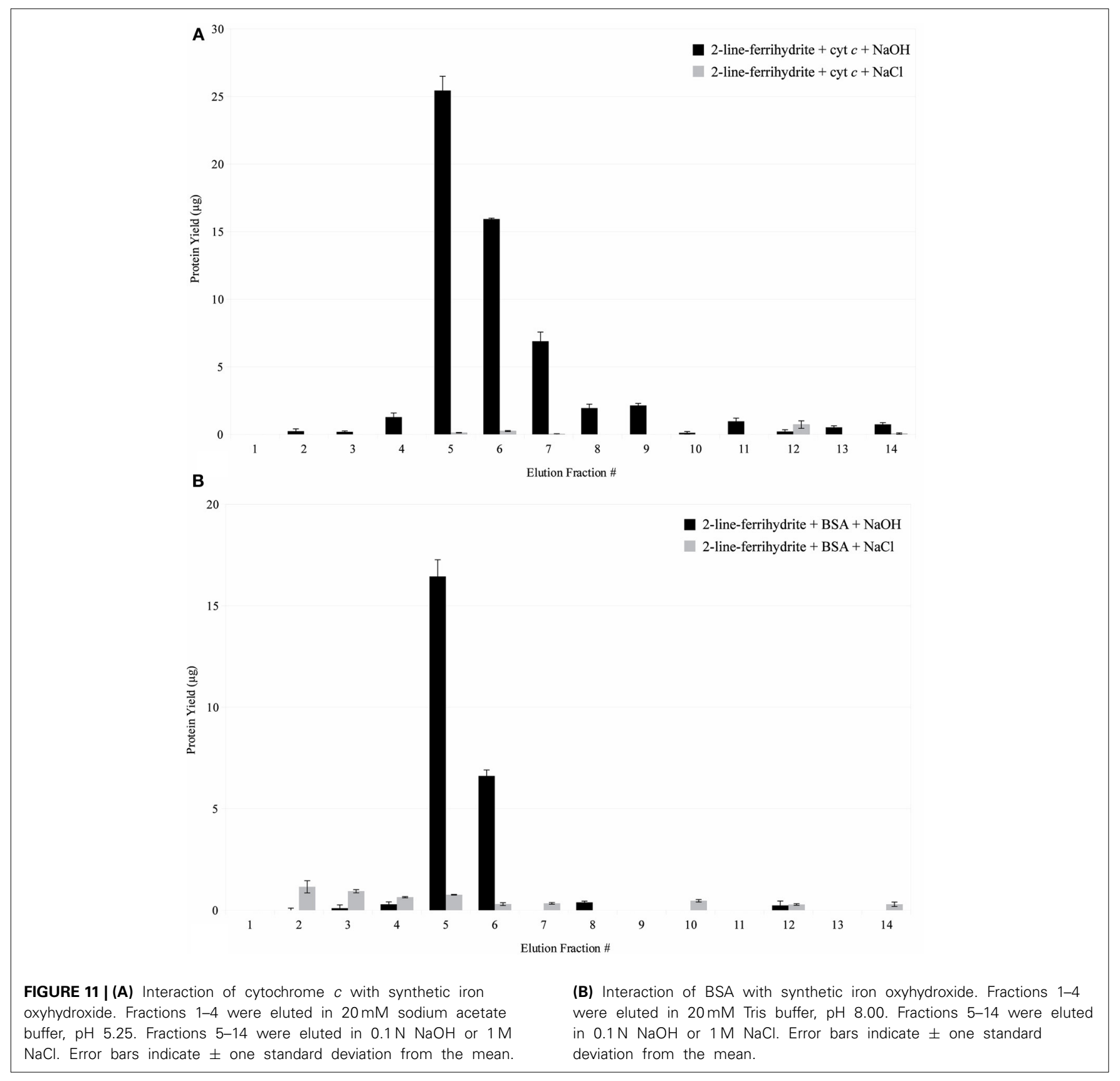

osmotic-shock method was employed to enrich for cytochrome $c$; instead an enrichment of acidic proteins was obtained. Only one basic protein $(\mathrm{pI}=9.4)$ was identified, which happened to be one of the proteins associated with $\mathrm{ABC}$ phosphate-transporters (NCBI GI number: 114777113). By increasing the $\mathrm{pH}$ of the extraction solution to $\mathrm{pH} 13$, all the proteins in $\mathrm{PV}$-1's proteome should in theory be above their $\mathrm{pI}$, which would make them negatively charged if they are expressed. This is a different approach from proteomic studies involving acidophilic $\mathrm{FeOB}$ where the $\mathrm{Fe}(\mathrm{III})$ is already dissolved in a strongly acidic medium or in acidic mine water and sonication of washed cells is not a problem (Ram et al., 2005; Bouchal et al., 2006). However, when this approach is taken for PV-1, a substantial amount of white paste remains, which seems to effectively bind to proteins in solution (i.e., no bands seen in gel stained with coomassie blue). This white paste has been mentioned by Emerson and Moyer (2002) as being organic matter originating from the stalks, but no characterization has yet been made. The use of $\mathrm{NaOH}$ along with SDS has long been used in alkaline lysis of bacterial cells (Birnboim and Doly, 1979) and more recently in yeast cells (Kushnirov, 2000). There have been also recent studies on soil proteomics that have used $\mathrm{NaOH}$ and SDS as the protein extraction solution, followed by a phenol extraction protocol to remove humic acids (Benndorf et al., 2007). The use of SDS alone can be effective in lysis of 
marine microorganisms (Fuhrman et al., 1988). In light of the results from these past studies, it is recommended that the $\mathrm{NaOH}$ solution used in this study to desorb proteins from biogenic iron oxides be complemented with SDS to maximize cell lysis of neutrophilic FeOB as well as to help solubilize membrane proteins in the crude extract.

The fact that the spiked proteins were easily adsorbed and desorbed from PV-1 mats, and the different behavior in synthetic 2LF, suggests that poorly crystalline iron oxyhydroxide is not the only substrate playing a role in adsorption/desorption of proteins. This can be explained by a close interaction of Fe and an organic polymer, which is consistent with different models that have been proposed for biomineral formation in PV-1 (Chan et al., 2011; Bennett et al., 2014). These results can also suggest that the proteins bound to PV-1 mats have the potential to be more accessible or bio-available than proteins bound to synthetic 2LF.

\section{CONCLUSION}

A method that yields sufficient biomass for proteomic analysis involving neutrophilic FeOB has been developed. Our method circumvents the problem of protein adsorption onto biominerals and shows that both acidic and basic proteins can be identified. Using the methods herein presented, a proteomic profile of M. ferrooxydans was produced but a full analysis will be described elsewhere. Our results indicate that the twisted-stalks produced by $M$. ferrooxydans not only bind strongly to proteins but also can desorb them more easily than synthetic 2LF. This leaves open the possibility that fields of iron mats seen in the ocean floor, such as the recently identified FeMO Deep site at the base of Löi'hi Seamount, near Hawaii (Edwards et al., 2011), are natural banks of bioavailable adsorbed protein, not only from neutrophilic FeOB, but from the rest of the microbial community surrounding it. This can in turn influence the growth of iron reducing bacteria that are known to be present in iron mats of Lōi'hi Seamount but are hypothesized to be carbon limited (Emerson, 2009).

\section{ACKNOWLEDGMENTS}

We would like to acknowledge the following persons for helping with our project: Dave Emerson for donating stock cultures of M. ferrooxydans, John Zhong for maintaining cultures, Anthony Kampf for assistance with XRD analysis, Beth Orcutt and Jason Sylvan for insightful comments and feedback. We would also like to acknowledge the Center for Dark Energy Biosphere Investigations (C-DEBI) for project support. This is C-DEBI contribution number 212.

\section{SUPPLEMENTARY MATERIAL}

The Supplementary Material for this article can be found online at: http://www.frontiersin.org/journal/10.3389/fmicb.2014. 00259/abstract

\section{REFERENCES}

Appelo, C. A., Van Der Weiden, M. J., Tournassat, C., and Charlet, L. (2002). Surface complexation of ferrous iron and carbonate on ferrihydrite and the mobilization of arsenic. Environ. Sci. Technol. 36, 3096-3103. doi: 10.1021/es010130n

Ausubel, F. M., Brent, R., Kingston, R. E., Moore, D. D., Seidman, J. G., Smith, J. A., et al. (1989). "Protein expression," in Current Protocols in Molecular Biology (New York, NY: John Wiley \& Sons), 16.1-16.8.
Bastida, F., Moreno, J. L., Nicolas, C., Hernandez, T., and Garcia, C. (2009). Soil metaproteomics: a review of an emerging environmental science. Significance, methodology and perspectives. Eur. J. Soil Sci. 60, 845-859. doi: 10.1111/j.13652389.2009.01184.x

Benndorf, D., Balcke, G. U., Harms, H., and von Bergen, M. (2007). Functional metaproteome analysis of protein extracts from contaminated soil and groundwater. ISME J. 1, 224-234. doi: 10.1038/ismej.2007.39

Benndorf, D., Vogt, C., Jehmlich, N., Schmidt, Y., Thomas, H., Woffendin, G., et al. (2009). Improving protein extraction and separation methods for investigating the metaproteome of anaerobic benzene communities within sediments. Biodegradation 20, 737-750. doi: 10.1007/s10532-009-9261-3

Bennett, S. A., Toner, B. M., Barco, R., and Edwards, K. J. (2014). Carbon adsorption onto $\mathrm{Fe}$ oxyhydroxide stalks produced by a lithotrophic iron-oxidizing bacteria. Geobiology 12, 146-156. doi: 10.1111/gbi.12074

Birnboim, H. C., and Doly. J. (1979). A rapid alkaline extraction procedure for screening recombinant plasmid DNA. Nucleic Acids Res. 7, 1513-1524. doi: 10.1093/nar/7.6.1513

Bouchal, P., Zdrahal, Z., Helanova, S., Janiczek, O., Hallberg, K. B., and Mandl, M. (2006). Proteomic and bioinformatic analysis of iron- and sulfur-oxidizing Acidithiobacillus ferrooxidans using immobilized $\mathrm{pH}$ gradients and mass spectrometry. Proteomics 6, 4278-4285. doi: 10.1002/pmic.200500719

Bremer, H., and Dennis, P. P. (1996). "Modulation of chemical composition and other parameters of the cell by growth rate," in Escherichia coli and Salmonella: Cellular and Molecular Biology, 2nd End., eds F. C. Neidhardt, R. Curtiss III, J. L. Ingraham, E. C. C. Lin, K. B. Low, B. Magasanik, W. S. Reznikoff, M. Riley, M. Schaechter, and H. E. Umbarger (Washington, DC: ASM Press), 1553-1569.

Chan, C. S., Fakra, S. C., Emerson, D., Fleming, E. J., and Edwards, K. J. (2011). Lithotrophic iron-oxidizing bacteria produce organic stalks to control mineral growth: implications for biosignature formation. ISME J. 5, 717-727. doi: 10.1038/ismej.2010.173

Cox, R. A. (2004). Quantitative relationships for specific growth rates and macromolecular compositions of Mycobacterium tuberculosis, Streptomyces coelicolor A3(2) and Escherichia coli B/r: an integrative theoretical approach. Microbiology 150, 1413-1426. doi: 10.1099/mic.0.26560-0

Dobrikova, A. G., Dimitrov, M. I., Taneva, S. G., and Petkanchin, I. B. (2007). Protein-coated $\beta$-ferric hydrous oxide particles. An electrokinetic and electrooptic study. Colloids Surf. B 56, 114-120. doi: 10.1016/j.colsurfb.2006.11.034

Edwards, K. J., Glazer, B. T., Rouxel, O. J., Bach, W., Emerson, D., Davis, R. E., et al. (2011). Ultra-diffuse hydrothermal venting supports Fe-oxidizing bacteria and massive umber deposition at $5000 \mathrm{~m}$ off Hawaii. ISME J. 5, 1748-1758. doi: 10.1038/ismej.2011.48

Edwards, K. J., McCollom, T. M., Konishi, H., and Buseck, P. R. (2003). Seafloor bioalteration of sulfide minerals: results from in situ incubation studies. Geochim. Cosmochim. Acta 67, 2843-2856. doi: 10.1016/S0016-7037(03) 00089-9

Emerson, D. (2009). Potential for iron-reduction and iron-cycling in iron oxyhydroxide-rich microbial mats at Loihi Seamount. Geomicrobiol. J. 26, 639-647. doi: 10.1080/01490450903269985

Emerson, D., and Floyd, M. M. (2005). Enrichment and isolation of iron-oxidizing bacteria at neutral pH. Meth. Enzymol. 397, 112-123. doi: 10.1016/S00766879(05)97006-7

Emerson, D., and Moyer, C. (1997). Isolation and characterization of novel ironoxidizing bacteria that grow at circumneutral pH. Appl. Environ. Microbiol. 63, 4784-4792.

Emerson, D., and Moyer, C. L. (2002). Neutrophilic-Fe-oxidizing bacteria are abundant at the Lo'ihi Seamount hydrothermal vents and play a major role in $\mathrm{Fe}$ oxide deposition. Appl. Environ. Microbiol. 68, 3085-3093. doi: 10.1128/AEM. 68.6.3085-3093.2002

Emerson, D., Rentz, J. A., Lilburn, T. G., Davis, R. E., Aldrich, H., Chan, C., et al. (2007). A novel lineage of Proteobacteria involved in formation of marine Fe-oxidizing microbial mat communities. PLoS ONE 2:e667. doi: 10.1371/journal.pone.0000667

Fuhrman, J. A., Comeau, D. E., Hagstrm, A., and Chan, A. M. (1988). Extraction from natural planktonic microorganisms of DNA suitable for molecular biological studies. Appl. Environ. Microbiol. 54, 1426-1429.

Gasteiger, E., Hoogland, C., Gattiker, A., Duvaud, S., Wilkins, M. R., Appel, R. D., et al. (2005). "Protein identification and analysis tools on the ExPASy server," in The Proteomics Protocols Handbook, ed J. M. Walker (Totowa, NJ: Humana Press), 571-607. 
Kato, S., Chan, C., Itoh, T., and Ohkuma, M. (2013). Functional gene analysis of freshwater iron-rich flocs at circumneutral $\mathrm{pH}$ and isolation of a stalkforming microaerophilic iron-oxidizing bacterium. Appl. Environ. Microbiol. 79, 5283-5290. doi: 10.1128/AEM.03840-12

Keiblinger, K. M., Wilhartitz, I. C., Schneider, T., Roschitzki, B., Schmid, E., Eberl, L., et al. (2012). Soil metaproteomics - comparative evaluation of protein extraction protocols. Soil Biol. Biochem. 54, 14-24. doi: 10.1016/j.soilbio.2012. 05.014

Keller, M., and Hettich, R. (2009). Environmental proteomics: a paradigm shift in characterizing microbial activities at the molecular level. Microbiol. Mol. Biol. Rev. 73, 62-70. doi: 10.1128/MMBR.00028-08

Kikuchi, S., Makita, H., Takai, K., Yamaguchi, N., and Takahashi, Y. (2014). Characterization of biogenic iron oxides collected by the newly designed liquid culture method using diffusion chambers. Geobiology 12, 133-145. doi: 10.1111/ gbi. 12073

Kiraga, J., Mackiewicz, P., Mackiewicz, D., Kowalczuk, M., Biecek, P., Polak, N., et al. (2007). The relationships between the isoelectric point and: length of proteins, taxonomy and ecology of organisms. BMC Genomics 8:163. doi: 10.1186/14712164-8-163

Knight, C. G., Kassen, R., Hebestreit, H., and Rainey, P. B. (2004). Global analysis of predicted proteomes: functional adaptation of physical properties. Proc. Natl. Acad. Sci. U.S.A. 101, 8390-8395. doi: 10.1073/pnas.0307270101

Kushnirov, V. V. (2000). Rapid and reliable protein extraction from yeast. Yeast 16, 857-860. doi: 10.1002/1097-0061(20000630)16:9\%3C857::AIDYEA561\%3E3.0.CO;2-B

Kützing, F. T. (1833). Sphaerotilus natans, eine neue Süsswasseralge. Linnaaea 8, 385-387.

Laemmli, U. K. (1970). Cleavage of structural proteins during the assembly of the head of bacteriophage T4. Nature 227, 680-685. doi: 10.1038/227680a0

Lafferty, B. J., and Loeppert, R. H. (2005). Methyl arsenic adsorption and desorption behavior on iron oxides. Environ. Sci. Technol. 39, 2120-2127. doi: $10.1021 /$ es048701+

Nesvizhskii, A., Keller, A., Kolker, E., and Aebersold, R. (2003). A statistical model for identifying proteins by tandem mass spectrometry. Anal. Chem. 75, 4646-4658. doi: 10.1021/ac0341261

Neu, H. C., and Heppel, L. A. (1965). The release of enzymes from Escherichia coli by osmotic shock and during the formation of spheroplasts. J. Biol. Chem. 240, 3685-3692.

Ogunseitan, O. A. (1993). Direct extraction of proteins from environmental samples. J. Microbiol. Meth. 17, 273-281. doi: 10.1016/0167-7012(93)90056-N

Pringsheim, E. G. (1949). Iron bacteria. Biol. Rev. 24, 200-245. doi: 10.1111/j.1469185X.1949.tb00575.x

Ram, R. J., VerBerkmoes, N. C., Thelen, M. P., Tyson, G. W., Baker, B. J., Blake II, R. C., et al. (2005). Community proteomics of a natural microbial biofilm. Science 308, 1915-1920. doi: 10.1126/science. 1109070

Rocker, C., Potzl, M., Zhang, F., Parak, W. J., and Nienhaus, G. U. (2009). A quantitative fluorescence study of protein monolayer formation on colloidal nanoparticles. Nat. Nanotechnol. 4, 577-580. doi: 10.1038/nnano.2009.195

Safi, M., Courtois, J., Seigneuret, M., Conjeaud, H, and Berret, J. F. (2011). The effects of aggregation and protein corona on the cellular internalization of iron oxide nanoparticles. Biomaterials. 32, 9353-9363. doi: 10.1016/j.biomaterials.2011.08.048

Saini, G., and Chan, S. (2013). Near-neutral surface charge and hydrophilicity prevent mineral encrustation of Fe-oxidizing micro-organisms. Geobiology 11, 191-200. doi: 10.1111/gbi.12021

Schwartz, R., Ting, C. S., and King, J. (2001). Whole proteome pI values correlate with subcellular localizations of proteins for organisms within the three domains of life. Genome Res. 11, 703-709. doi: 10.1101/gr.GR-1587R

Schwertmann, U., and Cornell, R. M. (2000). Iron Oxides in the Laboratory: Preparation and Characterization. Hoboken, NJ: Wiley-VCH. doi: 10.1002/9783527613229

Singer, E., Emerson, D., Webb, E. A., Barco, R. A., Kuenen, J. G., Nelson, W. C., et al. (2011). Mariprofundus ferrooxydans PV-1 the first genome of a marine $\mathrm{Fe}(\mathrm{II})$ oxidizing Zetaproteobacterium. PLoS ONE 6:e25386. doi: 10.1371/journal.pone. 0025386

Toner, B. M., Santelli, C. M., Marcus, M. A., Wirth, R., Chan, C. S., McCollom, T., et al. (2009). Biogenic iron oxyhydroxide formation at mid-ocean ridge hydrothermal vents: juan de Fuca Ridge. Geochim. Cosmochim. Acta 73, 388-403. doi: 10.1016/j.gca.2008.09.035

VerBerkmoes, N. C., Denef, V. J., Hettich, R. L., and Banfield, J. F. (2009). Systems biology: functional analysis of natural microbial consortia using community proteomics. Nat. Rev. Microbiol. 7, 196-205. doi: 10.1038/nrmic ro 2080

Vizcaino, J. A., Deutsch, E. W., Wang, R., Csordas, A., Reisinger, F., Ríos, D., et al. (2014). ProteomeXchange provides globally co-ordinated proteomics data submission and dissemination. Nat. Biotechnol. 30, 223-226. doi: 10.1038/ nbt.2839

Wang, H., and Edwards, K. J. (2009). Bacterial and archaeal DNA extracted from inoculated experiments: implication for the optimization of DNA extraction from deep-sea basalts. Geomicrobiol. J. 26, 463-469. doi: $10.1080 / 01490450903060814$

Conflict of Interest Statement: The authors declare that the research was conducted in the absence of any commercial or financial relationships that could be construed as a potential conflict of interest.

Received: 25 March 2014; accepted: 12 May 2014; published online: 30 May 2014. Citation: Barco RA and Edwards KJ (2014) Interactions of proteins with biogenic iron oxyhydroxides and a new culturing technique to increase biomass yields of neutrophilic, iron-oxidizing bacteria. Front. Microbiol. 5:259. doi: 10.3389/fmicb. 2014.00259

This article was submitted to Extreme Microbiology, a section of the journal Frontiers in Microbiology.

Copyright (C) 2014 Barco and Edwards. This is an open-access article distributed under the terms of the Creative Commons Attribution License (CC BY). The use, distribution or reproduction in other forums is permitted, provided the original author(s) or licensor are credited and that the original publication in this journal is cited, in accordance with accepted academic practice. No use, distribution or reproduction is permitted which does not comply with these terms. 